\title{
Developing Workplace Awareness through Project Work
}

\author{
Faridah Musa1, Maslawati Mohamad ${ }^{2}$, Sithaletchemy Krishnaiyer ${ }^{1}$, Wahiza Wahi ${ }^{1}$ \\ ${ }^{1}$ Pusat Citra Universiti, Universiti Kebangsaan Malaysia, Bangi, Malaysia \\ ${ }^{2}$ Faculty of Education, Universiti Kebangsaan Malaysia, Bangi, Malaysia \\ Email: faridahm@ukm.edu.my
}

Received 31 December 2015; accepted 26 April 2016; published 29 April 2016

Copyright (C) 2016 by authors and Scientific Research Publishing Inc.

This work is licensed under the Creative Commons Attribution International License (CC BY). http://creativecommons.org/licenses/by/4.0/

(c) (7) Open Access

\begin{abstract}
Studies have been carried out to investigate problems and causes of low employability amongst graduates from both public and private higher learning institutions. Although higher learning institutions have made concerted efforts to address this problem - to improve graduate employability, it remains a matter of serious concern. One of the main reasons for candidates not being employed is lack of communication skills particularly in English. Project work has been recognized as an effective way to develop students' communication skills, knowledge, experience and soft skills. In order to enable students to be more employable and aware of the requirements of the industry, a workplace related research project was assigned to students who took a course in Workplace Communication II at University Kebangsaan Malaysia (UKM), a public university. The aims of the study were to find out if project work developed students' understanding on workplace environments and what they learnt from it. Respondents in this study wrote their self-reflection by responding to questions in a Google doc survey after completing the project. The class teacher also commented on the progress made by the respondents in her field notes report. The findings show that involvement in project work has created awareness of the needs, requirements and workplace environment of the respondents' future jobs. They have learned social skills and teamwork, time management, personal development and report writing skills. This project work has given the necessary exposure which made them realize the importance of equipping themselves with the relevant skills and qualities sought after by prospective employers.
\end{abstract}

\section{Keywords}

Workplace Awareness, Graduate Employability, Project Work, Soft Skills, Generic Skills

\section{Introduction}

The $21^{\text {st }}$ century workplace is a far cry from its predecessors in that it now demands that the workforce already 
possesses the required workplace competencies and workplace readiness. In fact, with the advent of computer mediated technology and the age of the internet, the manner in which the workplace is conceived and constructed has transformed drastically. According to a report by the Partnership for $21^{\text {st }}$ century skills, "Today's graduates need to be critical thinkers, problem solvers, and effective communicators who are proficient in both core subjects and new, twenty-first-century content and skills". Some of the $21^{\text {st }}$ century skills are critical thinking, creativity, communication, collaboration, college and career readiness, effective oral and written communication, problem solving, accessing and analyzing information, all of which are highly sought after by the industry.

According to Pearlman (2006), in an increased globalised world, "the new work environment requires responsibility and self-management, as well as interpersonal and project-management skills that demand teamwork and leadership." This has a direct implication on how undergraduates are trained and equipped to enter the workplace. The Malaysian government, in particular, the Ministry of Higher Education and Malaysian employers have also recognized the need for our graduates to be competent and employable. In fact, the challenge today is not only to secure employment but to remain employed and to avoid being made redundant. The 2014 Budget indicates the government's emphasis on the importance of inculcating excellence in human capital. The Malaysian Prime Minister, Datuk Seri Najib Tun Razak highlighted that the government would focus on strengthening public and private higher learning institutions towards producing quality graduates who meet the demands of the job market (Sathesh, 2014).

The Ministry of Higher Education has also called upon all public institutions of higher learning to include elements of soft skills and other workplace related competencies into their courses. This move becomes even more significant as Malaysian employers have also voiced their grouses over the inability of fresh graduates to perform at the workplace. In a main stream local newspaper, The Star Online, dated 4 March, 2012, it was noted that, "graduates emerging from the Malaysian education system fail to meet the expectations of prospective employers due to a lack of critical thinking skills and poor communication". Education, human resource and recruitment consultants expressed that critical thinking skills must be fostered into the Malaysian education system in order to equip our students with relevant skills and knowledge for employment purposes. It could be concluded from the same report that our educational institutions are yet to sufficiently prepare our undergraduates with critical thinking skills and other relevant skills to fulfill the industrial demands.

It is in this scenario that the project work incorporated into the workplace communication course becomes significant and relevant. Many of the skills acquired through project work are highly sought after by employers - the ability to work well with others and handle interpersonal conflicts, make thoughtful decisions, practice and solve complex problems (Kloppenborg \& Baucus, 2004). According to Bell (2010) project work which stems from project based learning approach promotes social learning because students practice communication, negotiation, and collaborative skills. The call by the Ministry of Higher Education to include the teaching and learning of courses specifically designed to inculcate soft skills and other competencies in public universities imply that undergraduates lack these competencies.

In UKM in particular, the concern that its graduates may lose their competitiveness was expressed by the Deputy Vice-Chancellor (Student and Alumni Affairs). This was attributed to the fact that UKM graduates are still being negatively perceived as being poor in English, lacking in leadership skills, confidence, critical thinking, team work and communication skills. These perceptions have a direct implication on the employability of its graduates. In fact, it was the Deputy Vice-Chancellor's hope that UKM's efforts to excel as a research university should not be at the expense of its students (Saiful Bahari, 2015). Since project work incorporates many of today's required workplace competencies and allows students to acquire and apply new knowledge in solving real world problems, a study was conducted to gauge if project work did develop workplace awareness among students.

This study attempted to answer the following research questions:

i) Did the project work develop the students' understanding on workplace environments?

ii) What did the students learn from the project work?

It is hoped that the findings of this study could generate some insights for course designers to look into the incorporation of similar project work in language courses. The following section discusses the underpinning theory within the context of this study.

\section{Literature Review}

\subsection{Theoretical Discussion}

The underpinning theory behind project work activity is constructivist theory. In completing their project, the 
students are actively involved in their own learning process. This is parallel with constructivist advocators' view, Tobias, \& Duffy (2009). They believe that active learning means students take charge and monitor their own learning process. Another constructivist proponent, Jordan et al. (2008), believes that active learning could result in better learning performance. Constructivists also advocate that knowledge is not solely transmitted from a teacher to a student but constructed by the learner himself (Vygotsky, 1978). In completing their project work in Workplace Communication II, the students were asked to search for a company or an institution which is related to their discipline. For example, a group of students from the Chemistry Program, Faculty of Sciences and Technology contacted and developed rapport with the chemists of a pharmaceutical factory. Then, they made appointments with the chemists and interviewed them to obtain detailed information regarding their job specifications, challenges and strategies they used to cope with those challenges in order to be effective employees in the pharmaceutical industry.

In carrying out the project work, they became autonomous learners and practised social skills. They drew their own plans and strategies to approach the targeted companies. Besides planning, they also learnt to organize and delegate work among team members. They also practised and applied their problem solving skills, time management and communication skills. They were also involved in the social process of learning (Vygotsky, 1978). They learnt to help build each others' knowledge and tolerate each other's differences when working collaboratively to achieve a common goal. They also learnt to interact with people from different walks of life and backgrounds. Apparently, working together as a team could reduce stress level because all the problems should be solved not individually but as a group. In short, the project work is aimed to develop students' generic attributes besides knowledge in the work related discipline.

Stemming from these discussions, it is crucial for our institution to embark a study on our own students who did project work in the aforementioned Workplace Communication II course. The researchers intended to identify if students' involvement in project work in our institution could also yield similar positive results. By doing so, the researchers were able to identify the impact of this project work on students' learning especially in preparing the students with knowledge and skills for the future workplace. A study carried out by Faridah et al. (2011) supports that project work contributes to the development of many soft skills with applications to the workplace which apparently will fulfill the needs of the $21^{\text {st }}$ century job market. Project work enabled the students to be in a culture of learning and exposure to new people and experiences which will help them prepare for their future employment.

\subsection{Employability and Generic Skills}

Graduate employability has become a main concern of higher education. Research has proven that employability requires the development of graduate attributes. Bowden et al. (2002) defined graduate attributes as the qualities, skills and understanding which students should develop during their undergraduate studies. The Australian Technology Network (ATN, 2000) defined graduate attributes as "the qualities, skills and understandings a university community expects its students to develop during their time at the institution and, consequently, shape the contribution they are able to make to their profession and as a citizen”.

Employers prefer graduates who possess generic skills besides their relevant subject specific skills, knowledge and understanding. A considerable amount of work has been published which lists the many generic or transferable skills that employers are looking for. Pool and Sewell (2007) proposed a model of employability and included generic skills as one of the model components. He further reported several scholarly works on employability in higher learning which includes The Pedagogy for Employability Group (2004) which provides a list of generic skills expected by employers. The generic skills include:

- imagination/creativity;

- adaptability/flexibility;

- willingness to learn;

- independent working/autonomy;

- working in a team;

- ability to manage others;

- ability to work under pressure;

- good oral communication;

- communication in writing for varied purposes/audiences;

- attention to detail; 
- time management;

- assumption of responsibility and for making decisions;

- planning, coordinating and organizing ability; and

- ability to use new technologies

University of Tasmania outlines a number of factors why universities should focus on generic graduate attributes which has been part of the outcome of their learning. One factor is that acquiring disciplinary knowledge is not sufficient and will not guarantee graduates a job at the completion of their degree. The ever-changing work environment requires graduates to be able to function efficiently and due to this, graduates must have the necessary skills to solve problems, communicate effectively with clients and colleagues, work in teams, think critically, be creative and have sound information technology skills. Another factor identified is the fact that quickly dated knowledge causes graduates to become flexible and adaptable to the changing conditions. They need to become lifelong learners, open to new ideas and new ways of learning and thinking. Graduates need to achieve and demonstrate to employers their acquisition of generic skills that can be applied in a number of contexts.

Undergraduates need to be provided with ample opportunities in developing generic attributes besides knowledge in the work related discipline. Generic attributes include communication, problem-solving, computer literacy, information literacy, and teamwork skills. Undeniably, knowledgeable and skilled graduates are in high demand for any job requirements. This fact is further strengthened by Yorke (2006) who states that for a graduate to be marketable, he or she needs to acquire a set of skills and knowledge which results in him being more marketable and successful in his career. It is the aim of the Workplace Communication II course to equip students with the above mentioned generic skills by assigning them this project work which requires them to carry out research in a company related to their field of study.

\subsection{Self-Reflection on Learning Experience}

Providing students with the opportunities to gain the necessary skills, knowledge, understanding and attributes is obviously important, but so too is providing opportunities for reflection on and evaluation of the learning experiences that have already taken place. Without these opportunities, students are unlikely to give full consideration to how far they have come in developing their employability skills and what they may need to do in order to develop them further. Moon (2004) provides a full discussion of the crucial role of reflection in the context of employability. Moon (2004) further explains the importance of reflection in the exploration of personal abilities at recruitment and also as a preparation for lifelong learning. This element of reflection and evaluation is also the key for students' self-development which will benefit them personally and professionally.

The Higher Education Academy (2005) has long been studying the role of personal development planning (PDP) in higher education. PDP is a highly appropriate vehicle for reflection and evaluation in this context, and as all students are now entitled to PDP as part of their university experience, it should be relatively straightforward to ensure that it is used to full effect in developing employability. The Higher Education Academy suggests that there is a strong link between PDP and employability. PDP could help students to:

1) plan, record and reflect upon their experiences in a way that develops their employment

2) related skills and self-awareness;

3) understand how their transferable skills might be applied in new settings;

4) make realistic and suitable career plans based upon their heightened self-knowledge;

5) demonstrate both their employment potential and their ability to manage their future career development

PDP also indicates increased self-esteem as a major part of employability. Students need to have the belief on their ability to succeed and be able to project this belief to the outside world. Nevertheless, in order to achieve a high level of self-esteem, graduates will also have to be realistic about their achievements and committed to lifelong learning. It is through this project work, students will be able to increase their self-esteem by applying and reflecting what they have learnt in the classroom. Representing themselves as UKM students, the respondents demonstrated the knowledge and ability that they had acquired when carrying out the interview during the field trip to the company. The experience gained at the company serves as a platform for graduates to reflect on their potentials and ability in relation to their future employment. This will further help graduates to plan and manage their career and professional development to secure their employability in future.

\section{Methodology}

In view of the research questions posed in this study, a case study approach was seen to be appropriate since the 
researchers' aim was to gain a comprehensive understanding of a situation and process rather than the outcome or product of the phenomena (Merriam, 2009).

\subsection{Instruments}

The researchers employed two research tools namely online openended self-reflection (Appendix A) and the class teacher's field notes. An online open-ended self-reflection was administered upon the completion of the assigned project work. The respondents answered the open-ended online reflection questions which would provide answers to the above mentioned two research questions of the study. The class teacher's field notes on the students' progress and activities was also another research tool as she acted as a participatory researcher in this study.

\subsection{The Setting}

A workplace related project was assigned to undergraduates who enrolled in Workplace Communication II course at UKMto equip undergraduates with the necessary $21^{\text {st }}$ Century skills aforementioned. The project work focused on researching and reporting on the needs and requirements related to their future job at a company. The project was conducted in groups of 4 - 5, with members who are in the same faculty. It was carried out in seven weeks (the course duration of Semester 3 or short semester). In completing the project work, the students were required to do Field trip, Oral Progress Report, Oral Presentation and Written Report. The project work was to meet several course objectives :

1) to acquire workplace related skills and competencies in an authentic manner;

2) to develop workplace awareness and readiness;

3) to expose students to real workplace environments

\subsection{Respondents}

The respondents within the age range of 20 - 22 years oldwere 21 second year undergraduates enrolled in a Workplace Communication II course at Pusat Citra, UKM. They Pusat Citra is a center which provides English courses and other courses such as self-development and generic courses for undergraduates in UKM. The respondents were students from two faculties-Faculty of Sciences and Technology, and Faculty of Economics and Management. This is the second English course taken by undergraduates who obtained at least band 5 in the Malaysian University Entrance Exam (MUET) and also those who obtained grade A- or A in the first English course that they had taken. (Band 5 denotes good user of English language).

\subsection{Companies}

During the field trip, the respondents in groups of 4 - 5 visited a company to conduct interviews and make observation. The companies they visited included accounting, printing, hiring companies, a faculty of a local university and also an Islamic Shariah compliance cooperation. The companies and personnel interviewed are as shown in Table 1.

\subsection{Data Analysis}

The responses in the open ended online survey were analyzed and coded according to themes. The themes were

Table 1. Details of companies visited.

\begin{tabular}{|c|c|c|}
\hline & Name of Companies & Personnel interviewed \\
\hline 1. & Malaysian Newsprint Industries Sdn Bhd, Mentakab, Pahang & Finance Executive \\
\hline 2. & Techno count, Bandar Baru Bangi, Selangor & General Manager \\
\hline 3. & Adecco Malaysia, Kuala Lumpur & Assistant Marketing Manager \\
\hline 4. & Faculty of Science, University Malaya, Kuala Lumpur & Lecturers \\
\hline 5. & Koperasi Syariah Angkasa Berhad (KOPSYA), Selangor & Chief Executive Officer \\
\hline
\end{tabular}


derived from the responses provided by the respondents and were then categorized into several skills and knowledge as listed in the findings. The data was analyzed qualitatively to ensure depth in findings. Students' responses were labeled (S) according to numbers. However, not all responses could be included in the data as some carried the same meaning, so only significant responses were selected and reported according to the themes identified. As this paper reports on the skills and knowledge students learnt from the project work, only data from questions 1, 3 and 4 of the open ended online survey (Appendix A) were analyzed and included .The teacher's field notes were analyzed and included in the findings according to the themes of the responses.

\section{Findings and Discussion}

This section reports on the findings in answering the two research questions: (i) Did the project work develop the students' understanding on workplace environments? (ii) What did the students learn from the project work?

The following are the skills and knowledge the respondents learnt while completing their project work:

1) Workplace Awareness

2) Social skills and teamwork

3) Time management

4) Personal development

5) Writing skills

\subsection{Workplace Awareness}

The project work has benefitted the respondents in enhancing their knowledge and understanding regarding their future work requirements and environment. Being students, they barely had the exposure to real work settings and environment resulting in not being aware of the workplace needs and requirements. The field trip gave them valuable experience as reported in the following excerpts:

"It opened up my mind as to what the actual scenario is in employment, today." (S8)

"This project also makes me more aware of the current demands of the employees especially for those who are freshly graduated." (S12)

"The project allows me to actually get a very close look on how my future working environment is going to be like." (S10)

"I am exposed to the real world environment. Help me to prepare for my working environment." (S14)

The teacher noted in her reflective notes that after the interview sessions, many of the respondents expressed that they are more aware of the importance of being dynamic and engaging in life-long learning as the demands in the workplace are constantly changing. They know that they always have to be creative and think out of the box as there are diverse ways to overcome problems. The knowledge shared by the officers during the interview sessions could also be considered when they want to troubleshoot the problems they might face in their future workplace. In conclusion, project work is able to create awareness amongst the students about the real working environment. It also enables them to prepare themselves with necessary skills needed to meet the expectations of prospective employers. Apparently, what they have learned from this project work will serve as a catalyst which will result in them working harder to be more marketable.

\subsection{Social Skills and Teamwork}

There are two other skills which respondents acquired in this project work: social skills and teamwork. They learnt the elements needed in teamwork in order to achieve a goal. The elements are identifying group members' strengths and weaknesses, and later capitalizing on the strengths in completing the project. They also learnt to manage people from diverse backgrounds. Other significant aspects which they acquired are they need to be self-driven in order to work faster and more effectively.

“... I learnt how to manage group of different people with different expertise." (S5)

"It made me enhance and further increase understanding about the dynamics of working with others in a team" (S8)

"Managing a team in this project give fresh perspective on my ability in identifying each member's strengths \& weaknesses; and manipulating those abilities effectively in order to complete the project." (S19)

"... I also learnt that in a team, we should not just wait for the others to give instruction or command to do 
the job.” (S15)

"I believe our group has a very good teamwork and synergy between us." (S12)

Based on the teacher's reflective notes, she claimed that good team work is highly necessary in producing an effective report. Effective groups normally started their work early by appointing a group leader. The group leader would delegate to each group member a task or the group members volunteer for the task. At the initial stage, they conducted a brainstorming session to generate ideas and delegate work. Group discussions enable the respondents to discuss, accept and reject others' ideas wisely (Chapelle, 2003). In order to prevent any free riders, the teacher made sure that for each oral progress report, all respondents reported on what they had done. The respondents also commented on each other's work and contribution which demonstrated commitment of each member in the project work. This also promotes active participation and better interdependence among respondents. Through group discussions, they started acquiring motivation, strategies and a positive attitude which are crucial in group work. Evidently, project work is able to achieve dual purposes-social skills and teamwork.

\subsection{Time Management}

Respondents also acknowledged that due to time constraints, they learnt to manage time wisely in completing the project work in seven weeks. A respondent was also involved in another program but managed to handle both at the same time.

"I learnt on how to manage time wisely. The time period to complete this project is short. I also have to handle a programme. The best part was I can handle both." (S9)

"I learn how to manage my time well because my friends and I should complete this project for only 7 weeks. So, we should plan our project carefully in a short time." (S21)

The teacher's reflective notes highlighted that due to limited class hours allocated for this project, the respondents had to convene outside class hours regularly to ensure that they could submit the report within the stipulated time given. Initially, the teacher instructed them to draw a Gantt chart and discussed the dates for progress reports or consultations. This was to ensure the respondents planned their work and adhered to the due dates given to them and not procrastinate and produce last minute work. The project work has enabled respondents to learn to manage their time wisely which allowed them to complete the tasks successfully within the limited time frame.

\subsection{Personal Development}

The project work has enabled the respondents to be aware of their own skills and develop their knowledge and experience for their personal development. The awareness includes realization of the importance in learning new knowledge, being lifelong learners and the need to think out of the box in order to be successful in the workplace. They also learnt to communicate appropriately with people who are of higher rank. These statements were concluded from the following online responses:

"the most important thing to be good employees is the willingness to learn new things" (S11)

"this project led me to be more a resourceful person who have passion and determination to survive in the workplace world." (S18)

"I learnt to communicate well, especially with high ranked person." (S4)

"After doing the project, I now realize that I need to be a life-long-learner." (S20)

"I learnt that thinking differently is crucial to be on top." (S17)

The teacher also shared her view points in her reflective notes. She mentioned that in the beginning, the respondents lacked confidence to carry out the interview but gradually, they could see its importance and put much effort in it because they realized its usefulness in their future undertakings. They hardly had the experience of going out to meet and interview officers who work in companies. They were also afraid of communicating in English. They had to prepare the questions and revise them several times to reduce errors. The teacher had conducted some practices and simulations of the interview sessions emphasizing on pronunciation, intonation, facial expressions, gestures and body movements. The respondents were also taught the importance of appropriate dress and work ethics at workplace. Gradually, these simulations and practices enabled the respondents to gain confidence in communicating with the officers at the company. Thus, the interview session conducted during the field trip in the project work has helped in improving the respondents' personal development. 


\subsection{Writing Skills}

The responses to the online questions show that the respondents had learnt proper techniques and strategies in writing a report. They learnt to conduct a study, analyze data, and write an effective report. In addition, they reported that they had learnt the importance of report writing, employing a proper format in report writing, and organize their findings. With regard to linguistics aspects, they mentioned that they had improved their vocabulary, grammar and sentence structure. These statements were derived from the following online responses:

"I learn how to make report with proper format, relevant findings and good structure." (S5)

"I have also learnt how to write a proper project, how to conduct a study and how to decipher and analyze data after transcribing. I have learnt how to conduct research and compile findings with regard of the main data source." (S8)

"Academically, I am sure the importance of writing is equally the same with speaking." (S16)

The online responses indicate that the respondents believed that they had developed report writing skills in doing the project work. This coincides with the remarks made by the teacher in her field notes. They learned to focus on details particularly in the process of report writing. The stages were learning to transcribe the interviews they had carried out, analyzing the data obtained and reporting the findings in a project report. The teacher monitored the respondents' progress during conferencing sessions. During these sessions, the teacher had to guide the respondents by checking and teaching the format, linguistics aspects of communication, sentence structure, grammar and content organization. It is also noted in the field notes that some of the respondents could not differentiate between writing a formal report and writing for leisure purposes. They had some difficulties in organizing the content and using the appropriate tenses, vocabulary and terminologies.

Teaching explicitly the format of report writing, mechanics of writing and grammar are very crucial to help the respondents in organizing their content and producing error free sentences. The teacher had to provide a few samples of previous reports which gave much help to the respondents with regard to organizing their content, selecting appropriate words and correcting their mechanics. The teacher also facilitated the respondents in analyzing the data and focused on developing and organizing the content with little attention given to correcting grammatical errors. This was done to encourage the respondents to express their ideas and not feel inhibited with their thought of producing grammatical errors. At the final stage of the report, the teacher highlighted the grammatical errors on the respondents' draft.

\section{Conclusion and Limitations}

The findings of this study have shown that project work has successfully developed undergraduates' understanding of workplace environments as the respondents have acquired many useful skills that are considered important in the workplace. The project work has enabled respondents to acquire not only knowledge and experience about workplace needs and requirements but other important skills namely time management, social and teamwork skills and report writing skills. Thus, the respondents have been made aware of their future workplace settings and environment which they may not have acquired in the classroom. In addition, they also learnt about personal development when they were engaged in this project work. The project work has successfully developed not only workplace awareness, but also the necessary $21^{\text {st }}$ Century generic skills and attributes which are considered important for graduates' future jobs.

The respondents' workplace awareness was investigated in this study through the execution of project work incorporated in the Workplace Communication II course. Their views and experiences while conducting the project work have been demonstrated to be robust and thorough as reflected in this study. The researchers attempted to explore the respondents' workplace awareness as much as possible by employing a case study approach, in which their reflections and their teacher's field notes were used to provide data. As with all such studies, there are limitations that offer opportunities for further research. This study was not able to delve in-depth into the respondents' absolute involvement in the project work given the fact that the project was conducted within a short semester, approximately seven weeks, compared to a typical semester. Another aspect of this study which the researchers consider as an important parameter was their inability to observe the extent to which the respondents develop their understanding on workplace environment outside the classroom boundaries. Future studies could explore this matter to provide broader perspectives and a more comprehensive picture of their overall understanding of workplaces. It has to be emphasized that the findings and conclusions of this study can only be generalized to the population from which the sample of interest has been drawn. Studies of a larger number of participants are deemed necessary to consolidate the findings. 


\section{Acknowledgements}

This work was supported by the Strategic Research Fund provided by Universiti Kebangsaan Malaysia (UKMPTS-2013-036).

\section{References}

Australian Technology Network (2000). Generic Capabilities of ATN University Graduates. http://www.clt.uts.edu.au/ATN.grad.cap.project.index.html

Bell, S. (2010). Project-Based Learning for the 21st Century: Skills for the Future. The Clearing House.

Bowden, J., Hart, G., King, B., Trigwell, K., \& Watts, O. (2002). Generic Capabilities of ATN University Graduates. http://www.clt.uts.edu.au/ATN.grad.cap.project.index.html

Chapelle, C. A. (2003). English Language Learning and Technology. Amsterdam: John Benjamins Publishing Company. http://dx.doi.org/10.1075/lllt.7

Faridah, M., Norlaila. M., Rozmel, A. L., \& Maryam, M. A. (2012). Project-Based Learning (PjBL): Inculcating Soft Skills in $21^{\text {st }}$ Century Workplace. Procedia: Social \& Behavioral Science, 59, 565-573.

http://www.missionliteracy.com/21st-century-skills.html

http://www.thestar.com.my/news/nation/2012/03/04/education-system-not-producing-thinking-graduates-say-experts/

Jordan, A., Carlile, O., \& Stack, A. (2008). Approaches to Learning: A Guide for Teachers. New York: McGraw Hill.

Kloppenborg, T. J., \& Baucus, M. S. (2004). Project Management in Local Nonprofit Organizations: Engaging Students in Problem Based Learning. Journal of Management Education, 28, 610-630. http://dx.doi.org/10.1177/1052562904266008

Merriam, S. B. (2009). Qualitative Research: A Guide to Design and Implementation. San Francisco, CA: Josse Bass,

Moon, J. (2004). Reflection \& Employability. In Learning and Employability Series. LTSN Generic Centre and ESECT Publications.

Pearlman, B. (2006). Students Thrive on Cooperation and Problem Solving. Edutopia. http://www.edutopia.org/new-skills-new-century

Pool, L. D., \& Sewell, P. (2007). The Key to Employability: Developing a Practical Model of Graduate Employability. Education + Training, 49, 277-289. http://www.emeraldinsight.com/doi/pdfplus/10.1108/00400910710754435 http://dx.doi.org/10.1108/00400910710754435

Saiful Bahri, K. (2015). UKM Graduates Need to be More Competitive. UKM News Portal 12 February 2015. http://www.ukm.my/news/Latest_News/ukm-graduates-needed-to-be-more-competitive/

Sathesh, R. (2014). Malaysian Graduates: Relevant yet Irrelevant? Astro Awani 10 October 2014.

The Higher Education Academy (2005). Hospitality, Leisure, Sport and Tourism Network. June 2005.

The Pedagogy for Employability Group (2004). Pedagogy for Employability.

Tobias, S., \& Duffy, T. M. (2009). Constructivist Instruction: Success or Failure? New York: Routledge. University of Tasmania.

Vygotsky, L. (1978). Interaction between Learning and Development. In M. Cole, V. John-Steiner, S. Scribner, \& E. Souberman (Eds.), Mind and Society (pp. 79-91). Cambridge, MA: Harvard University Press.

Yorke, M. (2006). Employability in Higher Education: What It Is and What It Is Not? In The ESECT Learning and Employability Series (No. 1). York: Higher Education Academy. 


\section{Appendix A: The Online Open Ended Self-Reflection}

\section{ZZZE3022 SELF REFLECTION OF PROJECT EVALUATION}

Please respond to the following questions.

1. How has the field trip to the company changed your perspective regarding:

a. workplace requirements? b. workplace challenges?

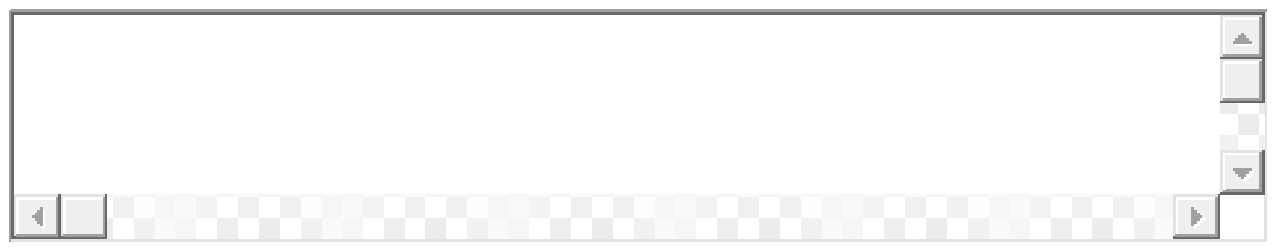

2. What are the constraints you faced in carrying out the project?

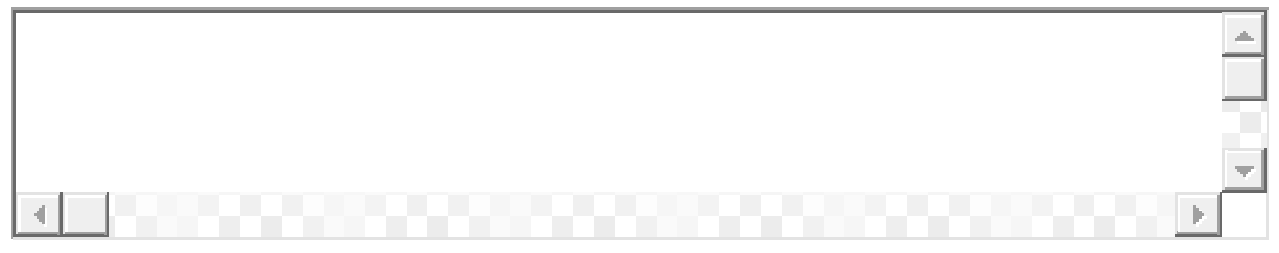

3. What is the most beneficial aspect you have gained in doing the project?

a. personally b. academically

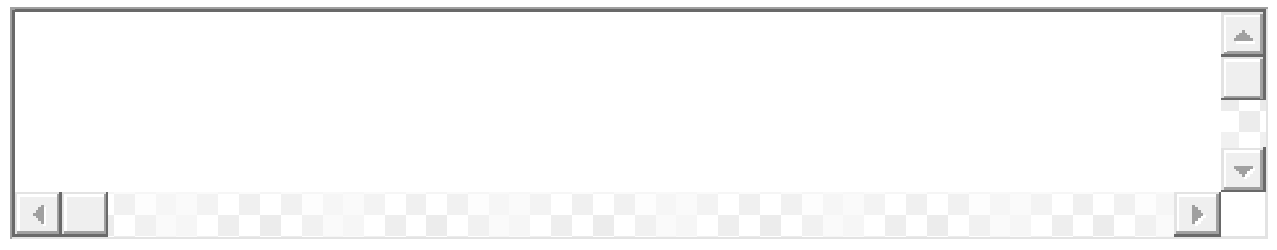

4. Based on what you have gained from the project, what do you intend to do to prepare yourself for the workplace?



5. What are your suggestions to improve the project for the course?

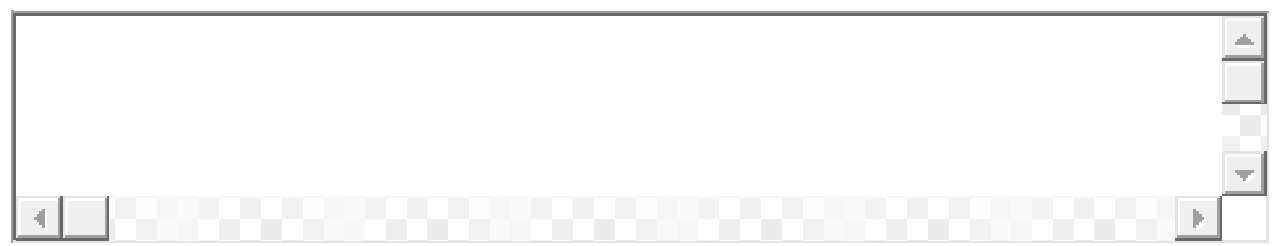

Name of company(s): 
Person(s) Interviewed \& Position 